\title{
THE OSSIFICATION OF THE CARPUS IN RICKETS, CONGENITAL SYPHILIS AND CRETINISM
}

BY

PATRICK MACARTHUR, M.B., СH.B.

(From the Department of Paediatrics, Glasgow University, and the Royal Hospital for Sick Children, Glasgow.)

It is generally believed that in rickets and cretinism there is delay in the appearance of the centres of ossification of the carpus, and some hold that there is a similar delay in congenital syphilis $\left(\mathrm{Köhler}^{6}\right.$, Holmes and Ruggles ${ }^{4}$ ). Recently Signorelli, Hosen and Miles ${ }^{9}$ have claimed that in rickets and congenital syphilis the time of appearance of these centres is normal.

In view of these contradictory findings the records of children admitted to the Royal Hospital for Sick Children during the last ten years suffering from these diseases were examined. In each case the diagnosis was established clinically and by skiagrams. The case reports and x-ray plates of 211 cases of active rickets under five years of age, fourteen cases of congenital syphilis and twenty of cretinism were examined.

Before studying the available material it was first necessary to establish a standard of normality. On investigating the literature on the subject it was found that there was considerable variation among the different

TABLE 1.

\begin{tabular}{|c|c|c|c|c|c|c|}
\hline & & & & & Female. & Male. \\
\hline $\begin{array}{l}\text { Capitate } \\
\text { Hamate } \\
\text { Triquetral } \\
\text { Lunate } \\
\text { Navicular } \\
\text { Trapezoid } \\
\text { Trapezium } \\
\text { Pisiform } \\
\text { Radial Epi } \\
\text { Ulnar Epip } \\
\text { First Metac }\end{array}$ & 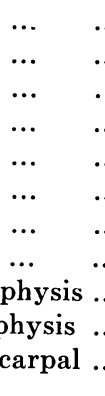 & $\begin{array}{l}\cdots \\
\cdots \\
\cdots \\
\cdots \\
\cdots \\
\cdots \\
\cdots \\
\cdots \\
\cdots \\
\cdots \\
\cdots\end{array}$ & $\begin{array}{l}\cdots \\
\cdots \\
\cdots \\
\cdots \\
\cdots \\
\cdots \\
\cdots \\
\cdots \\
\cdots \\
\cdots \\
\cdots\end{array}$ & $\begin{array}{l}\cdots \\
\cdots \\
\cdots \\
\cdots \\
\cdots \\
\cdots \\
\cdots \\
\cdots \\
\cdots \\
\cdots \\
\cdots\end{array}$ & $\begin{array}{l}3-6 \text { months } \\
5-10,, \\
2-3 \text { years } \\
3-4 \quad, \\
4-5, ", \\
4-5, ", \\
4-5 \quad, \\
9-10, \\
\text { About } 8 \text { months } \\
5-7 \text { years } \\
\text { Early 3rd year }\end{array}$ & $\begin{array}{c}4-10 \text { months } \\
6-12,, \\
\text { About } 3 \text { years } \\
,, 4,, \\
4-5 \text { years } \\
5-6,, \\
5-6, " \\
12-13,, \\
\text { About } 15 \text { months } \\
6-8 \text { years } \\
2-3 \text {," }\end{array}$ \\
\hline
\end{tabular}

Pryor's standard of NORMal ossification of the carpus. 
authorities regarding the age at which the carpal centres appear in the normal child. Pryor's ${ }^{7}$ tables, though old, are accurate, detailed and comprehensive and are based on radiological examination. They differ in some respects from the anatomical tables of Quain ${ }^{8}$, Debierre ${ }^{1}$ and Gray $^{3}$ and from those of Feer ${ }^{10}$, Holt and McIntosh", and Fujinami ${ }^{2}$, all based on radiological evidence and from a table compiled from examination of a large number of x-ray plates of normal wrists at the Royal Hospital for Sick Children. To overcome this difficulty two tables were utilized, viz., that compiled by Pryor $^{7}$ (table 1) and a composite table constructed from the standards of normality suggested by the other workers mentioned above (table 2). In both these tables the age at which the lower epiphyseal centres

TABLE 2.

\begin{tabular}{|c|c|c|c|c|c|c|c|}
\hline Capitate & $\ldots$ & $\ldots$ & $\ldots$ & $\ldots$ & $\ldots$ & Birth to & 1 yea \\
\hline Hamate & $\ldots$ & $\ldots$ & $\ldots$ & $\ldots$ & $\ldots$ & Birth to & 1 yea \\
\hline Triquetral & $\ldots$ & $\ldots$ & $\ldots$ & $\ldots$ & $\ldots$ & 2 to $3 \frac{1}{2}$ & years \\
\hline Lunate & $\ldots$ & $\ldots$ & $\ldots$ & $\ldots$ & $\ldots$ & 3 to $5 \frac{1}{2}$ & , \\
\hline Trapezium & $\ldots$ & $\ldots$ & $\ldots$ & $\ldots$ & $\ldots$ & 4 to $5 \frac{1}{2}$ & , \\
\hline Trapezoid & $\ldots$ & $\ldots$ & $\ldots$ & $\ldots$ & $\ldots$ & 4 to 6 & , \\
\hline Navicular & $\ldots$ & $\ldots$ & $\ldots$ & $\ldots$ & $\ldots$ & 5 to 6 & ", \\
\hline Pisiform & $\ldots$ & $\ldots$ & $\ldots$ & $\ldots$ & $\ldots$ & 10 to 12 & , \\
\hline Radial Epi] & hysis & $\ldots$ & $\ldots$ & $\ldots$ & $\ldots$ & 1 to $2 \frac{1}{2}$ & , \\
\hline Ulnar Epip & hysịs & $\ldots$ & $\ldots$ & $\ldots$ & $\ldots$ & 4 to 7 & , \\
\hline First Metac & arpal & $\ldots$ & $\ldots$ & $\ldots$ & $\ldots$ & 2 to 3 & , \\
\hline
\end{tabular}

COMPOSITE STANDARD OF NORMAL OSSIFICATION COMPILED FROM QUAIN, Feer, Debierre, Holt and McIntosh, Fujinami, Gray, Pryor and Royal Hospital for Sick Children records.

of the radius and ulna and the epiphyseal centre of the first metacarpal appeared were included. The pathological series here presented was compared with both these standards. When using Pryor's tables the differences in ossification in the two sexes were taken into consideration, but in comparing this material with the composite table, sex has been disregarded as no data are available.

Applying Pryor's standard, table 3 shows the number of cases in this series showing advanced, normal or delayed ossification in the three diseases

TABLE 3.

\begin{tabular}{|c|c|c|c|c|c|c|c|}
\hline \multirow[t]{3}{*}{ Rickets ... } & $\cdots$ & $\ldots$ & $\ldots$ & Advanced & $18(9$ & per & cent.) \\
\hline & & & & Normal & $141(66$ & , & $,, \quad)$ \\
\hline & & & & Delayed & $52(25$ &, & $, \quad)$ \\
\hline \multirow[t]{3}{*}{ Congenital } & syphilis & $\cdots$ & $\ldots$ & Advanced & 7 & & \\
\hline & & & & Normal & 6 & & \\
\hline & & & & Delayed & 1 & & \\
\hline \multirow[t]{3}{*}{ Cretinism } & $\ldots$ & $\ldots$ & $\cdots$ & Advanced & $\mathbf{0}$ & & \\
\hline & & & & Normal & $\mathbf{0}$ & & \\
\hline & & & & Delayed & 20 & & \\
\hline
\end{tabular}

OSSIFICATION OF CARPUS IN RICKETS, CONGENITAL SYPHILIS AND CRETINISM FOMPARED WITH PRYOR'S STANDARD. 
under consideration, while table 4 gives the results when compared with the composite standard. In the latter the range of normality is wide and consequently a larger number appear to show normal ossification. The difference in the number of cases appearing in the two tables is due to the fact that with the composite standard it is impossible to determine whether there is any retardation in the appearance of the centres till the patient reaches the age of one year, while, using Pryor's table, it is pcssible to detect delay after the age of six months.

TABLE 4.

\begin{tabular}{|c|c|c|c|c|c|c|c|}
\hline Rickets ... & $\ldots$ & $\ldots$ & $\ldots$ & Advanced & $13(6$ & per & cent.) \\
\hline & & & & Normal & $150(73$ & ," &,$\quad$ ) \\
\hline & & & & Delayed & $44(21$ & & \\
\hline Congenital & syphilis & $\ldots$ & $\ldots$ & Advanced & 2 & & \\
\hline & & & & Normal & 11 & & \\
\hline & & & & Delayed & 0 & & \\
\hline Cretinism & $\ldots$ & $\ldots$ & $\ldots$ & Advanced & 0 & & \\
\hline & & & & Normal & 1 & & \\
\hline & & & & Delayed & 15 & & \\
\hline
\end{tabular}

OSSIFICATION OF CARPUS IN RICKETS, CONGENITAL SYPHILIS AND CRETINISA COMPARED WITH COMPOSITE STANDARD.

Both comparisons, however, show a similar result for each disease. In at least 75 per cent. of the cases of rickets ossification was normal or advanced and only in about 25 per cent. was it delayed. In the congenital syphilis series only one case showed delay in ossification and this was only apparent with Pryor's standard. In cretinism, on the other hand, there was delay in all the cases save one and that only when compared to the composite scale which is a less exacting standard than that of Pryor. On the whole the present results are in accord with the findings of Signorelli and his co-workers9. In one respect, however, they are not in agreement with their conclusions, namely, that the late appearance of the carpal centres is in itself diagnostic of cretinism, for in about 25 per cent. of the present cases of rickets the centres of ossification have appeared late.

No explanation has been found to account for this delay. The patients showed the characteristic bony changes of rickets and none of the signs of cretinism, and at no particular age was the retardation specially manifest; for, when the cases were classified in age groups, the tendency to delay was no more marked in one group than in another. The question whether severe deficiency in the phosphorus content of the blood might afford an explanation of the delay was also taken into consideration. As the phosphorus had been estimated in a large number of cases the state of ossification was compared with the biochemical findings. From this it appeared that while on the whole there was a parallelism between the degree of reduction in serum phosphorus and the extent of the delay in ossification this was not always the case; in some cases with delayed ossification and active rickets as shown by x-ray, the phosphorus content of the serum was 
normal. This, however, may be due to the fact that the phosphorus may rise to the normal level within a few weeks from the beginning of treatment while the radiological signs of calcification take longer to appear.

\section{Summary.}

These records indicate that ossification is almost invariably delayed in cretinism, frequently advanced and seldom delayed in congenital syphilis and delayed in about 25 per cent. of cases of rickets. In view of the delay in the appearance of the carpal centres of ossification in some cases of rickets without any signs of hypothyroidism it does not seem justifiable to claim that this is in itself diagnostic of congenital thyroid deficiency.

Acknowledgement and thanks are due to Dr. Leonard Findlay and the present members of the staff for permission to use their case records and for much helpful advice and criticism.

\section{REFERENCES.}

1. Debierre, C., Cunningham's Anatomy (3rd Ed.), London, 1909, 207.

2. Fujinami, K., Abt's Pediatrics, London, 1923, I, 284.

3. Gray, H., Gray's Anatomy, London, 1930, 339.

4. Holmes, G. W., \& Ruggles, H. E., Röentgen Interpretation, London, 1919, 32.

5. Holt, L. E., \& McIntosh, R., Diseases of Infancy and Childhood, (10th Ed.), London, 1933, 612.

6. Köhler, A., Röntgenology, (2nd Ed.), London, 1935, 29.

7. Pryor, J. W., Quoted by Abt's Paediatrics, London, 1923, I, $2 \varepsilon 4$.

8. Quain, J., Quain's Anatomy (11th Ed.), London, 1915, IV, part 1, 166.

9. Signorelli, .J., Hosen, H., \& Miles, J. M., J. Pediatr., St. Louis, 1935, VII, 182.

10 Thiemich. M., Feer's Pediatrics. London, 1922, 29. 